\title{
MEKANISME PENENTUAN MARGIN PADA TRANSAKSI PEMBIAYAAN MURABAHAH
}

\author{
KHOZAINUL ULUM \\ FAI Unisla Lamongan \\ ozaaveroes@email.com
}

\begin{abstract}
Sharia banks, one of which activities are channeling funds with the principle of Murabahah (Buy-Sell), of course carry out these transactions in accordance with applicable regulations, namely in accordance with the DSN fatwa No. 04 / DSN-MUI / IV2000 regarding Murabahah, which is the contract used in the sale and purchase of goods by stating the cost of goods and the profit (margin) agreed upon by the seller and the buyer. In murabahah in Islamic banks, we as customers have agreed with the bank to buy goods, where the goods are first purchased by the Islamic bank, then sell them back to customers with a predetermined and mutually agreed rate of profit margin. At first glance, we do not see a difference in the amount of installments between installments at conventional banks and those in Islamic banks. What we need to underline here is the form / scheme of each type of channeling funds from the bank. For conventional banks, banks channel funds by providing credit / loans in the form of money. This means that here a conventional bank sells its money in the hope of a profit rate determined by interest. Meanwhile, Islamic banks distribute funds in the form of sale and purchase, where the BS buys an asset / asset which then sells it back to the customer at the level of profit that has been agreed at the beginning. Where according to PBI No. 7/46 / PBI / 2005 that "the agreement margin must be determined once at the beginning of the contract and does not change during the contract period". This shows that there will be no change in installments during the financing period with the Indonesian murabahah scheme
\end{abstract}

Keywords: margin, Murabahah, DSN MUI, Harga Pokok, Jual beli

Abstrak: Bank Syariah yang salah satu kegiatannya adalah menyalurkan dana dengan prinsip Murabahah (Jual-Beli) tentu melakukan transaksi tersebut harus seuai dengan ketentuan yang berlaku yaitu sesuai dengan fatwa DSN No. 04/DSN-MUI/IV2000 mengenai Murabahah, yaitu akad yang dipergunakan dalam perjanjian jual beli barang dengan menyatakan harga pokok barang dan keuntungan (marjin) yang disepakati oleh penjual dan pembeli. Dalam murabahah di bank syariah, kita sebagai nasabah telah sepakat dengan bank untuk membeli barang, dimana barang tersebut dibeli dulu oleh bank syariah, kemudian menjualnya kembali ke nasabahnya dengan tingkat margin keuntungan yang telah ditentukan dan disepakati bersama. Sepintas kita tidak melihat perbedaan dalam jumlah angsuran antara mencicil di bank konvensional dengan mengangsur di bank syariah. Yang perlu kita garis bawahi disini adalah bentuk/skema dari masing-masing jenis penyaluran dana dari bank tersebut. Untuk Bank konvensional, bank menyalurkan dana dengan memberikan kredit / pinjaman dalam bentuk uang. Artinya disini bank konvensional menjual uangnya dengan harapan tingkat keuntungan yang ditentukan dengan bunga. Sedangkan Bank syariah menyalurkan dana dalam bentuk jual beli, dimana BS membeli sebuah aktiva / asset yang kemudian menjualnya kembali kepada nasabah dengan tingkat 
keuntungan yang telah disepakati diawal. Dimana menurut PBI No. 7/46/PBI/2005 bahwa "Kesepakatan marjin harus ditentukan satu kali pada awal Akad dan tidak berubah selama periode Akad". Hal ini menunjukan bahwa tidak akan ada perubahan angsuran selama jangka waktu pembiayaan dengan skema murabahah

Kata Kunci: margin, Murabahah, DSN MUI, Harga Pokok, Jula beli 

Mekanisme Penentuan Margin...

\section{A. Pendahuluan}

Islam adalah agama yang universal sebagai pedoman yang mengatur segala aspek kehidupan manusia, pada garis besarnya menyangkut dua bagian pokok, yaitu ibadah dan muamalah. Ibadah adalah mengahambakan diri kepada Allah SWT dengan menaati segala perintah-Nya dan menjauhi segala larangan-Nya. Sedangkan muamalah ialah kegiatankegiatan yang menyangkut antar manusia yang meliputi aspek ekonomi, politik dan sosial. Untuk kegiatan muamalah yang menyangkut aspek ekonomi seperti jual beli, simpan pinjam, hutang piutang, usaha bersama dan lain sebagainya.

Adapun bentuk-bentuk jual beli yang telah dibahas oleh para ulama dalam fiqh muamalah Islamiyah terbilang sangat banyak. Jumlahnya bisa mencapai belasan atau puluhan. Sesungguhpun demikian, dari sekian banyak itu, ada salah satu jenis jual beli yang telah banyak dikembangkan sebagai sandaran pokok dalam pembiayaan modal kerja dan investasi dalam perbankan syariah, yaitu bai' al-murabahah atau jual beli murabahah.

\section{B. Metode Penelitian}

Penelitian ini bertujuan mendinkripsikan mekanisme penentuan margin pada pemebiayaan murabahah di Lembaga keuanagan Syariah (LKS). Pendekatan yang digunakan peneliti adalah pendekatan Kuwalitatif. Adapaun data dihumpun peneliti dari sumber sekunder yang berupa Fatwa DSN MUI dan berbagai litetartur. Data dianalisis dengan menggunakan teknik analisis deskriptif.

\section{Hasil dan Pembahasan}

\section{Definisi Al-Murabahah}

Kata al-Murabahah diambil dari bahasa Arab dari kata ar-ribhu (الرِبْحُ) yang berarti kelebihan dan tambahan (keuntungan), atau murabahah juga berarti AlIrbaah karena salah satu dari dua orang yang bertransaksi memberikan keuntungan kepada yang lainnya (Ibnu Al-Mandzur., hal. 443.). sedangkan secara istilah, Bai’ul murabahah adalah: 


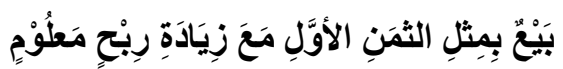

Yaitu jual beli dengan harga awal disertai dengan tambahan keuntungan (Azzuhaili, 1997., hal. 3765). Definisi ini adalah definisi yang disepakati oleh para ahli fiqh, walaupun ungkapan yang digunakan berbeda-beda. (Asshawy, I990., hal.198.)

Menurut Para ahli hukum Islam mendefinisikan bai' al-murabahah sebagai berikut :

I. 'Abd ar-Rahman al-Jaziri mendefinisikan bai' al-murabahah sebagai menjual barang dengan harga pokok beserta keuntungan dengan syarat-syarat tertentu.

2. Menurut Wahbah az-Zuhaili adalah jual-beli dengan harga pertama (pokok) beserta tambahan keuntungan.

3. Ibn Rusyd --filosof dan ahli hukum Maliki-- mendefinisikannya sebagai jualbeli di mana penjual menjelaskan kepada pembeli harga pokok barang yang dibelinya dan meminta suatu margin keuntungan kepada pembeli.

4. Ibn Qudamah --ahli hukum Hambali-- mengatakan bahwa arti jual-beli murabahah adalah jual-beli dengan harga pokok ditambah margin keuntungan.

Dengan kata lain, jual-beli murabahah adalah suatu bentuk jual-beli di mana penjual memberi tahu kepada pembeli tentang harga pokok (modal) barang dan pembeli membelinya berdasarkan harga pokok tersebut kemudian memberikan margin keuntungan kepada penjual sesuai dengan kesepakatan. Tentang "keuntungan yang disepakati”, penjual harus memberi tahu pembeli tentang harga pembelian barang dan menyatakan jumlah keuntungan yang ditambahkan pada biaya tersebut.

Para ahli hukum Islam menetapkan beberapa syarat mengenai jual-beli murabahah. Wahbah az-Zuhaili mengatakan bahwa di dalam bai' al-murabahah itu disyaratkan beberapa hal, yaitu :

I. Mengetahui harga pokok 
Mekanisme Penentuan Margin...

Dalam jual-beli murabahah disyaratkan agar mengetahui harga pokok/ harga asal karena mengetahui harga merupakan syarat sah jual-beli. Syarat ini juga diperuntukkan untuk jual-beli at-tauliyyah dan al-wadi’ah.

2. Mengetahui keuntungan

Hendaknya margin keuntungan juga diketahui oleh si pembeli. Karena margin keuntungan termasuk bagian dari harga, sedangkan mengetahui harga merupakan syarat sah jual-beli.

3. Harga pokok merupakan sesuatu yang dapat diukur, dihitung dan ditimbang, baik pada waktu terjadi jual-beli dengan penjual yang pertama atau setelahnya, seperti dirham, dinar, dan lain-lain.

Jual-beli murabahah merupakan jual-beli amanah, karena pembeli memberikan amanah kepada penjual untuk memberitahukan harga pokok barang tanpa bukti tertulis. Dengan demikian, dalam jual-beli ini tidak diperbolehkan berkhianat. Allah telah berfirman :

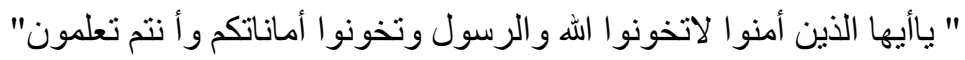

Berdasarkan ayat di atas, apabila terjadi jual-beli murabahah dan terdapat cacat pada barang, baik pada penjual maupun pada pembeli, maka dalam hal ini ada dua pendapat ulama. Menurut Hanafiyah, penjual tidak perlu menjelaskan adanya cacat pada barang karena cacat itu merupakan bagian dari harga barang tersebut. Sementara jumhur ulama tidak memperbolehkan menyembunyikan cacat barang yang dijual karena hal itu termasuk khianat. Penyembunyian cacat barang atau tidak menjelaskannya menurut hukum Islam dianggap sebagai suatu pengkhianatan dan merupakan salah satu cacat kehendak ('aib min 'uyub al-iradah) yang berakibat pembeli diberi hak khiyar atau --dalam bahasa hukum perdata Barat-- pembeli diberi hak untuk minta pembatalan atas jual-beli tersebut. Ibn Juzai dari Mazhab Maliki mengatakan, "Tidak boleh ada penipuan jual-beli murabahah dan jual-beli lainnya". Termasuk penipuan adalah menyembunyikan keadaan barang yang sebenarnya 
yang tidak diingini oleh pembeli atau mengurangi minatnya terhadap barang tersebut.

Pengkhianatan dalam jual-beli murabahah ini bisa terjadi mengenai informasi tentang cara penjual memperoleh barang, yaitu apakah melalui pembelian secara tunai, pembelian hutang atau sebagai penggantian dari suatu kasus perdamaian. Pengkhianatan bisa juga terjadi tentang besarnya harga pembelian.

Apabila pengkhianatan terjadi dalam hal informasi cara memperoleh barang, dimana misalnya penjual menyatakan bahwa ia memperolehnya melalui pembelian tunai padahal melalui pembelian hutang atau merupakan barang penggantian dalam suatu kasus perdamaian, maka pembeli diberi hak khiyar untuk meneruskan atau membatalkan akad tersebut. Atau dalam bahasa hukum perdata, pengkhianatan ini merupakan suatu cacat kehendak dan memberikan hak kepada pembeli untuk meminta pembatalan akad tersebut.

Apabila pengkhianatan terjadi mengenai harga pokok barang di mana penjual menyatakan suatu harga yang lebih tinggi dari harga sebenarnya yang ia bayar, maka dalam hal ini ada perbedaan pendapat dalam mazhab Hanafi. Menurut Abu Hanifah, pembeli boleh melakukan khiyar untuk meneruskan jual-beli atau membatalkannya karena murabahah merupakan akad jual-beli yang berdasarkan amanah. Menurut Abu Yusuf (I33-I82 H), pembeli tidak mempunyai hak khiyar, melainkan berhak menurunkan harga ke tingkat harga riil sesungguhnya yang dibayarkan oleh penjual ketika membeli barang bersangkutan serta penurunan margin keuntungan dalam prosentase yang sebanding dengan penurunan harga pokok barang. Mazhab Maliki sejalan dengan pendapat Abu Hanifah. Sedangkan mazhab Syafíi dan Hambali sejalan dengan pendapat Abu Yusuf.

Bai' al-murabahah tidak memiliki rujukan/referensi langsung dari alQur'an dan Sunnah. Yang ada hanyalah referensi mengenai jual-beli dan 
Mekanisme Penentuan Margin...

perdagangan. Jual-beli murabahah ini hanya dibahas dalam kitab-kitab fiqih dan itupun sangat sedikit dan sepintas saja. Para ilmuwan, ulama, dan praktisi perbankan syari'ah agaknya menggunakan rujukan/dasar hukum jual-beli sebagai rujukannya, karena mereka menganggap bahwa murabahah termasuk jual-beli.

\section{Landasan Hukum}

Landasan hukum akad murabahah ini adalah:

\section{Al-Quran}

Ayat-ayat Al-Quran yang secara umum membolehkan jual beli, diantaranya adalah firman Allah:

\section{وَأَحَلَّ اللهُ الْبَيْعَ وَحَرَّمَ الرِّبَا}

Artinya: "..dan Allah menghalalkan jual beli dan mengharamkan riba" (QS. AlBaqarah:275).

Ayat ini menunjukkan bolehnya melakukan transaksi jual beli dan murabahah merupakan salah satu bentuk dari jual beli.

Dan firman Allah:

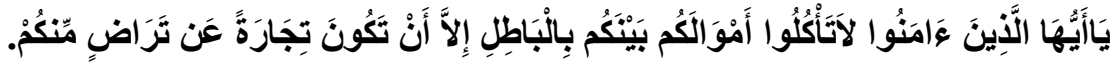

Artinya: "Hai orang-orang yang beriman, janganlah kamu saling memakan harta sesamamu dengan jalan yang batil, kecuali dengan jalan perniagaan yang berlaku dengan suka sama suka diantara kamu” (QS. An-Nisaa:29).

Dan firman Allah:

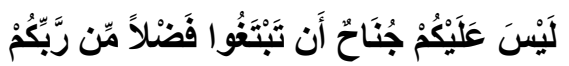

Artinya: "Tidak ada dosa bagimu mencari karunia (rezki hasil perniagaan) dari Rabbmu” (QS. Al-Baqarah:198)

Berdasarkan ayat diatas, maka murabahah merupakan upaya mencari rezki melalui jual beli. Murabahah menurut Azzuhaili (1997., hal.3766.) adalah jual beli berdasarkan suka sama suka antara kedua belah pihak yang bertransaksi. 


\section{Assunnah}

Sabda Rasulullah Shallallahu 'Alaihi Wassallam: "Pendapatan yang paling afdhal (utama) adalah hasil karya tangan seseorang dan jual beli yang mabrur". (HR. Ahmad Al Bazzar Ath Thabrani).

Hadits dari riwayat Ibnu Majah, dari Syuaib:

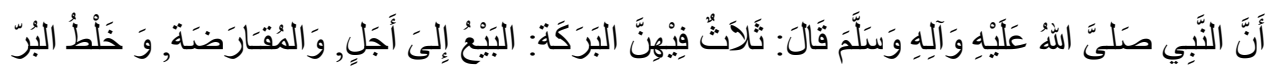

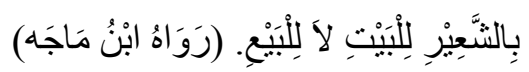

"Tiga perkara yang didalamnya terdapat keberkahan: menjual dengan pembayaran secara tangguh, muqaradhah (nama lain dari mudharabah), dan mencampur gandum dengan tepung untuk keperluan rumah dan tidak untuk dijual” (HR. Ibnu Majah).

Ketika Rasulullah Shallallahu 'Alaihi Wassallam akan hijrah, Abu Bakar Radhiyallahu 'Anhu, membeli dua ekor keledai, lalu Rasulullah Shallallahu 'Alaihi Wassallam berkata kepadanya, "jual kepada saya salah satunya", Abu Bakar Radhiyallahu 'Anhu menjawab, "salah satunya jadi milik anda tanpa ada kompensasi apapun", Rasulullah Shallallahu 'Alaihi Wassallam bersabda, "kalau tanpa ada harga saya tidak mau".

Sebuah riwayat dari Ibnu Mas'ud Radhiyallahu 'Anhu, menyebutkan bahwa boleh melakukan jual beli dengan mengambil keuntungan satu dirham atau dua dirham untuk setiap sepuluh dirham harga pokok (Azzuhaili, 1997, hal 3766).

Selain itu, transaksi dengan menggunakan akad jual beli murabahah ini sudah menjadi kebutuhan yang mendesak dalam kehidupan. Banyak manfaat yang dihasilkan, baik bagi yang berprofesi sebagai pedagang maupun bukan. 
Mekanisme Penentuan Margin...

\section{Al-Ijma}

Transaksi ini sudah dipraktekkan di berbagai kurun dan tempat tanpa ada yang mengingkarinya, ini berarti para ulama menyetujuinya (Ash-Shawy, I990., hal. 200.).

4. Kaidah Fiqh, yang menyatakan:

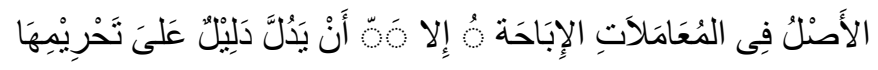

"Pada dasarnya, semua bentuk muamalah boleh dilakukan kecuali ada dalil yang mengharamkannya."

\section{Fatwa Dewan Syari'ah Nasional}

a. Nomor 4/ DSN-MUI IV/ 2000 tanggal I April 2000 tentang Murabahah,

b. Nomor I3/ DSN-MUI IX/ 2000 tanggal I6 September 2000 tentang Uang Muka Dalam Murabahah,

c. Nomor I6/ DSN-MUI IX/ 2000 tanggal I6 September 2000 tentang Diskon Dalam Murabahah,

d. Nomor I7/ DSN-MUI IX/ 2000 tanggal I6 September 2000 tentang Sanksi Atas Nasabah Mampu Yang Menunda-nunda Pembayaran, dan

e. Nomor 23/ DSN-MUI/ III/ 2002 tanggal 28 Maret 2002 tentang Potongan Pelunasan Dalam Murabahah.

Berdasarkan fatwa-fatwa tersebut, Bank Indonesia mengatur lebih lanjut dalam bentuk Peraturan Bank Indonesia atau Surat Edaran Bank Indonesia, seperti tentang kolektibilitas dan Pedoman Akuntansi Perbankan Syari’ah Indonesia (PAPSI). Sesuai UU No.I0/I998 tentang perubahan UU No.7 tentang Perbankan dalam penjelasan pasal 6 huruf $m$ dijelaskan bahwa yang mempunyai kewenangan untuk mengatur kegiatan usaha Bank Syari’ah adalah Bank Indonesia.

\section{Rukun Dan Syarat Sahnya Jual Beli Murabahah}

Rukun murabahah adalah:

I. Adanya pihak-pihak yang melakukan akad, yaitu:

\section{Penjual}


Pembeli

2. Obyek yang diakadkan, yang mencakup:

$\square$ Barang yang diperjualbelikan

$\square$ Harga

3. Akad/Sighat yang terdiri dari:
Ijab (serah)
Qabul (terima)

Selanjutnya masing-masing rukun diatas harus memenuhi syarat-syarat sebagai berikut:

I. Pihak yang berakad, harus:

Cakap hukum.

$\square$ Sukarela (ridha), tidak dalam keadaan terpaksa atau berada dibawah tekanan atau ancaman.

2. Obyek yang diperjualbelikan harus:

Tidak termasuk yang diharamkan atau dilarang.

Memberikan manfaat atau sesuatu yang bermanfaat.

$\square$ Penyerahan obyek murabahah dari penjual kepada pembeli dapat dilakukan.

$\square$ Merupakan hak milik penuh pihak yang berakad.

$\square$ Sesuai spesifikasinya antara yang diserahkan penjual dan yang diterima pembeli.

3. Akad/Sighat

Harus jelas dan disebutkan secara spesifik dengan siapa berakad.

$\square$ Antara $i j a b$ dan qabul (serah terima) harus selaras baik dalam spesifikasi barang maupun harga yang disepakati.

Tidak mengandung klausul yang bersifat menggantungkan keabsahan transaksi pada kejadian yang akan datang.

Selain itu ada beberapa syarat-syarat sahnya jual beli murabahah adalah sebagai berikut:

a. Mengetahui Harga pokok

Volume. 8/No. 2/Juli 2020 Al-Iqtishod| 35 
Mekanisme Penentuan Margin...

Harga beli awal (harga pokok) harus diketahui oleh pembeli kedua, karena mengetahui harga merupakan salah satu syarat sahnya jual beli yang menggunakan prinsip murabahah. Mengetahui harga merupakan syarat sahnya akad jual beli, dan mayoritas ahli figh menekankan pentingnya syarat ini. Bila harga pokok tidak diketahui oleh pembeli maka akad jual beli menjadi fasid (tidak sah) (Al-Kasany, hal.3 I93). Pada praktek perbankan syariah, Bank dapat menunjukkan bukti pembelian obyek jual beli murabahah kepada nasabah, sehingga dengan bukti pembelian tersebut nasabah mengetahui harga pokok Bank.

b. Mengetahui Keuntungan

Keuntungan seharusnya juga diketahui karena ia merupakan bagian dari harga. Keuntungan atau dalam praktek perbankan syariah sering disebut dengan margin murabahah dapat dimusyawarahkan antara bank sebagai penjual dan nasabah sebagai pembeli, sehingga kedua belah pihak, terutama nasabah dapat mengetahui keuntungan bank.

c. Harga pokok dapat dihitung dan diukur.

Harga pokok harus dapat diukur, baik menggunakan takaran, timbangan ataupun hitungan. Ini merupakan syarat murabahah. Harga bisa menggunakan ukuran awal, ataupun dengan ukuran yang berbeda, yang penting bisa diukur dan di ketahui.

d. Jual beli murabahah tidak bercampur dengan transaksi yang mengandung riba.

e. Akad jual beli pertama harus sah.

Bila akad pertama tidak sah maka jual beli murabahah tidak boleh dilaksanakan. Karena murabahah adalah jual beli dengan harga pokok ditambah keuntungan, kalau jual beli pertama tidak sah maka jual beli murabahah selanjutnya juga tidak sah (Azzuhaily, hal. 3767-3770). 


\section{Modal Dan Unsur Pendukung}

Suatu sistim ekonomi Islam harus bebas dari bunga. Dalam sistem itu bunga tidak diperkenankan memainkan pengaruhnya yang merugikan pekerja, produksi dan distribusi. Dengan alasan inilah, modal telah menduduki tempat yang khusus dalam ilmu ekonomi Islam. Dalam hal ini kita cenderung menganggap modal "sarana produksi yang menghasilkan” tidak sebagai faktor produksi pokok, melainkan sebagai suatu perwujudan tanah dan tenaga kerja sesudahnya. Modal pribadi adalah sesuatu yang diharapkan pemiliknya akan memberikan penghasilan padanya.

Yang dianggap paling penting dalam hal ini adalah bahwa modal dapat juga tumbuh dalam masyarakat yang bebas bunga. Janganlah lupa bahwa Islam memperbolehkan adanya laba yang berlaku sebagai insentif untuk menabung. Lagi pula hanya sistem ekonomi Islam yang dapat menggunakan modal dengan benar dan baik, karena dalam sistem kapitalis modern kita dapati bahwa manfaat kemajuan teknik yang dicapai oleh ilmu pengetahuan hanya bisa dinikmati oleh masyarakat yang relatif kaya, yang pendapatannya melebihi batas pendapatan untuk hidup sehari-hari.

Mereka yang hidup sekedar cukup untuk makan sehari-hari terpaksa harus tetap menderita kemiskinan abadi. Tetapi Islam melindungi kepentingan si miskin dengan memberikan tanggung jawab moral terhadap si kaya untuk memperhatikan si miskin. Kedua, Islam mengakui sistim hak milik pribadi secara terbatas, setiap usaha apa saja yang mengarah ke penumpukan kekayaan yang tidak layak dalam tangan segelintir orang. Demikianlah dalam kitab suci Al-Qur'an dinyatakan agar si kaya mengeluarkan sebagaian dari rezekinya untuk kesejahteraan masyaraka, karena kekayaan harus tersebar dengan baik.

Islam mengakui modal serta perananya dalam proses produksi. Islam juga mengakui bagian modal dalam kekayaan nasional hanya sejauh mengenai sumbangannya yang ditentukan sebagai persentase laba yang berubah-ubah dan diperoleh, bukan dari persentase tertentu dari kekayaan itu sendiri. 
Mekanisme Penentuan Margin...

Dalam arti terbatas, teori Islam mengenai modal tidak saja mengakui gagasan klasik tentang penghematan dan produktivitas, tetapi juga gagasan Keyness tentang preferensi likuiditas, karena dalam Islam modal itu produktif dalam arti bahwa tenaga kerja yang dibantu oleh modal akan lebih menghasilkan dari pada yang tanpa modal.

Laba yang diperkenankan oleh Islam adalah hasil investasi dalam produksi yang merupakan proses memakan waktu. Motif laba, merangsang seseorang menabung dan menginvestasi, dengan demikian menunda konsumsi sekarang untuk waktu yang akan datang.

Teori Islam mengenai modal lebih realistik, luas, mendalam, dan etik daripada teori modern tentang modal. Realistik, karena produktivitas modal yang mengalami perubahan berkaitan dengan kenyataan produksi yang dianggap mudah berubah dalam keadaan pertumbuhan yang dinamis. Luas dan mendalam karena ia memperhatikan semua variabel seperti mata uang, jumlah penduduk, penemuan baru, kebiasaan, selera, tingkat hidup, ketinggalan waktu dan sebagainya.

Etik karena keikutsertaannya dalam berbagai bidang di suatu negara Islam harus bersifat adil dan wajar, juga harus bebas dari pengisapan para pelaku produksi lainnya, sehingga menyumbang terciptanya kekayaan nasional. Karena itu dalam kerangka sosial Islami, bunga yang ditetapkan pada modal tidak diperbolehkan menimbulkan dampak yang merugikan ekonomi. dengan kata lain, Islam yakin akan perekonomian yang bebas bunga.

\section{Jenis-Jenis Murabahah}

Murabahah pada prinsipnya adalah jual beli dengan keuntungan, hal ini bersifat dan berlaku umum pada jual beli barang-barang yang memenuhi syarat jual beli murabahah. Dalam prakteknya pembiayaan murabahah yang diterapkan Bank Bukopin Syariah terbagi kepada 3 jenis, sesuai dengan peruntukannya, yaitu:

I. Murabahah Modal Kerja (MMK), yang diperuntukkan untuk pembelian barangbarang yang akan digunakan sebagai modal kerja. Modal kerja adalah jenis 
pembiayaan yang diperlukan oleh perusahaan untuk operasi sehari-hari. Penerapan murabahah untuk modal kerja membutuhkan kehati-hatian, terutama bila obyek yang akan diperjualbelikan terdiri dari banyak jenis, sehingga dikhawatirkan akan mengalami kesulitan terutama dalam menentukan harga pokok masing-masing barang.

2. Murabahah Investasi (MI), adalah pembiayaan jangka menengah atau panjang yang tujuannya untuk pembelian barang modal yang diperlukan untuk rehabilitasi, perluasan, atau pembuatan proyek baru.

3. Murabahah Konsumsi (MK), adalah pembiayaan perorangan untuk tujuan nonbisnis, termasuk pembiayaan pemilikan rumah, mobil. Pembiayaan konsumsi biasanya digunakan untuk membiayai pembelian barang konsumsi dan barang tahan lama lainnya. Jaminan yang digunakan biasanya berujud obyek yang dibiayai, tanah dan bangunan tempat tinggal.

Al-Bai' Naqdan wal Murabahah Muajjal, bayar cicilan. Dalam praktek yang dilakukan oleh bank syariah saat ini adalah murabahah berdasarkan pesanan, sifatnya mengikat dengan pembayaran tangguh. Dalam perbankan, murabahah lazimnya dilakukan dengan cara pembayaran cicilan (bitsaman ajil). Dalam transaksi ini barang diserahkan segera setelah akad sedangkan pembayaran dilakukan secara tangguh.

\section{Mekanisme Penentuan Marjin Dalam Murabahah Bank Syariah}

Secara teknis, yang dimaksud marjin keuntungan adalah peresentase tertentu yang diterapkan per tahun perhitungan marjin keuntungan secara harian, maka jumlah hari dalam setahun ditetapkan 360 hari, perhitungan marjin keuntungan secara bulanan, maka setahun ditetapkan 12 bulan.

\section{Referensi Marjin Keuntungan}

Yang dimaksud dengan Referensi Marjin Keuntungan adalah marjin keuntungan yang ditetapkan dalam rapat ALCO Bank syariah. Penetapan marjin 
Mekanisme Penentuan Margin...

keuntungan pembiayaan berdasarkan rekomendasi, usul dan saran dari tim ALCO

Bank Syariah, dengan mempergunakan beberapa hal sebagai berikut:

I. Direct Compotiter's Market Rate (DCMR), ialah tingkat marjin keuntungan rata-rata perbankan syariah.

2. Indirct Competitor's Market Rate (ICMR), ialah tingkat suku bunga rata-rata perbankan konvensional.

3. Expected Competitive Return for Investors (ECRI), target bagi hasil kompetitif yang diharapkan dapat diberikan kepada dana pihak ketiga.

4. Acquiring Cost, biaya yang dikeluarkan oleh bank yang langsung terikat dengan upaya yang dikeluarkan oleh bank yang langsung terikat dengan upaya untuk memperoleh dana pihak ketiga

5. Overhead Cost, biaya yang dikeluarkan oleh bank yang tidak langsung terikat dengan upaya untuk memperoleh dana pihak ketiga.

\section{Penetapan Harga Jual}

Setelah memperoleh referensi marjin keuntungan, bank melakukan penetapan harga jual. Harga jual adalah penjumlahan harga jual/harga pokok/harga perlehan bank dan marjin keuntungan.

\section{Pengakuan Angsuran Harga Jual}

Pengakuan angsuran dapat dihitung dengan menggunakan empat metode, yaitu :

I. Metode marjin keuntungan menurun (sliding) ialah perhitungan marjin keuntungan yang semakin menurun sesuai dengan menurunnya harga pokok sebagai akibat adanya cicilan/angsuran harga pokok yang dibayar nasabah setiap bulan menurun.

2. Marjin keuntungan rata-rata ialah marjin keuntungan menurun yang perhitungannya secara tetap dan jumlah angsuran dibayar nasabah tetap setiap bulan 
3. Marjin keuntungan flat ialah perhitungan marjin keuntungan terhadap nialai harga pokok pembiayaaan secara tetap dari satu periode ke periode lainnya, walaupun baki debetnya menurun sebagai akibat dari adanya angsuran harga pokok

4. Marjin keuntungan annuitas ialah marjin keuntungan yang diperoleh dari perhitungan secara annuitas. Yakni suatu cara pengembalian pembiayaan dengan pembayaran angsuran harga pokok dan marjin keuntungan secara tetap. Perhitungan ini akan menghasilkan pola angsuran harga pokok yang semakin membesar dan marjin keuntungan yang semakin menurun.

\section{Persyaratan untuk perhitungan marjin keuntungan}

Marjin keuntungan $=\mathrm{f}$ (plafond) hanya bisa dihitung apabila komponenkomponen yang dibawah ini :

I. Jenis perhitungan marjin keuntungan

2. Plafond pembiayaan sesuai jenis

3. Jangka waktu pembayaran

4. Tingkan marjin keuntungan pembiayaan

5. Pola tagihan atau jatuh tempo tagihan (baik harga pokok maupun marjin keuntungan). Tanggal jatuh tempo tagihan merupakan tanggal yang tidak termasuk dalam perhitungan dari marjin keuntungan.

\section{Contoh-Contoh Perhitungan Marjin Keuntungan}

Marjin keuntungan menurun

I. Nasabah dengan plafond, PLFN = Rp. I00.000.000.00

2. Jangka waktu pembiayaan I tahun

3. Tingkat marjin keuntungan setahun, $\mathrm{MRJ}=16 \%$

Maka jadwal angsuran pembiayaan sebagai berikut :

Volume. 8/No. 2/Juli 2020 Al-Iqtishod| 35 
Mekanisme Penentuan Margin...

- Angsuran harga pokok per bulan, $\mathrm{APPB}=(\mathrm{PLFN} / \mathrm{I} 2)=8,333,333,33$

- Pencairan I0-I0-2010 sejumlah Rp. 100,000,000.00

\begin{tabular}{|l|l|l|l|}
\hline No. & Tanggal & Pokok & Marjin Keuntungan \\
\hline I. & I0-II-20I0 & APPB & (PLFN-(No-I) APPB) MRJ)/I2 \\
\hline 2. & I0-I2-20I0 & APPB & (PLFN-(No-I) APPB) MRJ)/I2 \\
\hline 3 & I0-0I-20I I & APPB & (PLFN-(No-I) APPB) MRJ)/I2 \\
\hline I2. & I0-II-20I I & APPB & (PLFN-(No-I) APPB) MRJ)/I2 \\
\hline
\end{tabular}

Jadi untuk menghitung angsuran ke 2 maka :

$\mathrm{APPB}=$ Pokok $=8,333,333.33$

$((\mathrm{PLFN}-(\mathrm{No}-\mathrm{I}) \mathrm{APBB}) \mathrm{MRJ}) / \mathrm{I} 2=$ Marjin euntungan $=$

$(($ IO0,000,000-(2-I) 8,333,333.33)0,I6/I2 = Rp. I,222,222.22

Angsuran (2)

Angsuran harga pokok $=$

Angsuran marjin keuntungan $=$

Rp. I,222,222.22

Rp. 9,555,555.55

Angsuran (5)

$\mathrm{APPB}=$ Pokok $=8,333,333.33$

$(\mathrm{I} 00,000,000-((5-\mathrm{I}) 8,333,333.33)$ 0,I6)/I2 = Rp. 888,888.88

Angsuran harga pokok $=\quad$ Rp. 8,333,333.33

Angsuran marjin keuntungan $=\quad$ Rp. $888,888.88$

Rp. 9,222,222.22 


\section{Simpulan}

Murabahah adalah suatu jenis pembiayaan yang termasuk dalam kategori penjualan dengan pembayaran tunda. Meskipun tidak didasarkan pada teks al-Quran dan Sunnah, namun dalam kajian fiqh Islam jenis transaksi ini dapat dibenarkan. Bank-bank Islam telah menggunakan kontrak murabahah dalam kativitas pembiayaan mereka dimana barangbarang dilibatkan dan bank telah memperluas cakupan dan tingkat penggunaannya. Pembiayaan semacam ini sekarang telah mencapai lebih dari tujuh puluh lima persen pembiyaan bank Islam berkat kemampuannya untuk memberikan keuntungan yang ditetapkan di muka dari investasi bank, sangat mirip dengan keuntungan yang ditetapkan di muka pada bank-bank berbasis bunga. Pembiayaan murabahah dan harga kreditnya yang lebih tinggi jelas menunjukkan bahwa ada nilai waktu dalam pembiayaan berbasis murabahah yang mendorong, meski secara tidak langsung, kepada pengakuan nilai waktu pada uang. Gampang sekali dilupakan bahwa mengakui nilai waktu pada uang secara logika menggiring kepada pengakuan terhadap bunga. Dengan mengakui nilai waktu dalam transaksi-transaksi murabahah dan kemudian penolakan hal yang sama dalam transaksitransaksi finansial, tampak sebagai sikap yang tidak konsisten dan tidak logis. Murabahah sebagai sebuah kegiatan kerjasama ekonomi antara dua pihak mempunyai bebrapa ketentuan yang harus dipenuhi dalam rangka meningkat jalinan kerja sama dimana bank membiayai pembelian yang diperlukan nasabah dengan sistem pembayaran ditangguhkan. Pembiayaan murabahah ini mirif dengan kredit modal kerja pada bank konvensional, karena itu jangka waktu pembiayaan tidak lebih dari satu tahun dan seringnya untuk pembiayaan yang bersifat konsumtif seperti rumah, tanah, toko, mobil, motor dan sebagainya.

\section{E. Daftar Pustaka}

Anshori, Abdul Ghofur. 2007. Payung Hukum Perbankan Syariah (UU di Bidan Perbankan, Fatwa DSN-MUI, dan Peraturan Bank Indonesia.Yogyakarta: UII Press

Volume. 8/No. 2/Juli 2020 Al-Iqtishod | 35 
Mekanisme Penentuan Margin...

Antonio, Muhammad Syafi'I. 200I. Bank Syariah Dari Teori ke Praktik. Jakarta: Gema Insani

Djuwaini, Dimyauddin. 2010. Pengantar Fiqh Muamalah, Yogyakarta: Pustaka Belajar

Karim, Ediwarman A. 20I3. Bank Islam; Analisis Fiqh dan Keuangan. Jakarta: RajaGrafindo Persada. 2013

Mannan, M.A., I997, Teori dan Praktek Ekonomi Islam, Yogyakarta: Dana Bhakti Prima Yasa

Muhamad, 2000, Sistem \& Prosedur Oprasional Bank Syariah, Yogyakarta: UII Press 